\title{
Pemanfaatan Smartphone Dan Media Sosial Untuk Promosi Online Serta Aplikasi Pembukuan Guna Memaksimalkan Kemajuan Teknologi Pada Umkm Di Kelurahan Joglo, Kecamatan Banjarsari
}

\author{
Hanif Safika Rizky ${ }^{1}$, Ika Swasti Putri ${ }^{2}$, Yuniatin Trisnawati DKW ${ }^{3}$ \\ Sekolah Tinggi Ilmu Ekonomi Adi Unggul Bhirawa Surakarta \\ e-mail: hanifsafika12@gmail.com ${ }^{1}$, ika@stie-aub.ac.id ${ }^{2}{ }_{\text {_yuniatintrisnawati@gmail.com }}{ }^{3}$
}

\begin{abstract}
Abstrak
Pada era Covid-19, berbagai aspek kehidupan serta kegiatan usaha mengalami berbagai dinamika yang mengalami perubahan dan adaptasi yang harus dilakkukan. Berbagai bisnis mengalami kendala dan penurunan omzet serta kesulitan bertahan di tengah- tengah situasi yang muncul secara tiba-tiba dan terjadi di seluruh dunia. UMKM merupakan salah satu usaha yang mengalami dampak dari pandemi tersebut. UMKM harus melakukan berbagai perubahan maupun strategi dan penyesuaian untuk kegiatan Bisnis. Perubahan strategi bisnis ini harus dilakukan melalui pemanfaatan teknologi yang dapat dilakukan melalui smartphone dan sosial media untuk menjaga lingkup konsumen yang lebih banyak menggunakan smartphone dalam situasi Pandemi. Tujuan dari Pengabdian masyarakat ini adalah untuk memaksimalkan teknologi pada UMKM di kelurahan joglo dengan memberikan solusi berupa : 1 Pendampingan penggunaan teknologi untuk melakukan promosi online dengan sosial media 2 . Pendampingan penggunaan smartphone untuk aplikasi Pembukuan Pengabdian dilaksanakan pada tahun 2021. Metode pengumpulan data melalui interview, observasi dan dokumentasi. Metode pelaksanaan kegiatan dilakukan dengan cara pelatihan dan pendampingan. Hasil Kegiatan pengabdian ini adalah UMKM yang mengikuti pelatihan, bisa menggunaan tekhnologi smartphone untuk promosi online dan pembukuan.
\end{abstract}

Kata kunci : Pembukuan melalui Aplikasi, Promosi Online, UMKM

\begin{abstract}
In the Covid-19 era, various aspects of life and business activities underwent various dynamics that experienced changes and adaptations that had to be done. Various businesses are experiencing problems and decreased turnover and difficulty surviving situations that arise suddenly and occur around the world. MSMEs are one of the businesses that have experienced the impact of the pandemic. MSMEs must make various changes as well as strategies and adjustments for business activities. This change in business strategy must be carried out through the use of technology that can be done through smartphones and social media to maintain the scope of consumers who use more smartphones in a pandemic situation. The purpose of this community service is to maximize technology at MSMEs in the joglo village by providing solutions in the form of: 1 Assistance in the use of technology to carry out online promotions with social media 2. Assistance in using smartphones for the Service Bookkeeping application is carried out in 2021. Data collection methods are through interviews, observation and documentation. The method of implementing activities is carried out by means of training and mentoring. The results of this service activity, MSMEs that take part in the training, can use smartphone technology for online promotions and bookkeeping.
\end{abstract}

Keywords: Bookkeeping through Applications, Online Promotion, UMKM

\section{PENDAHULUAN}

Situasi pandemi Covid-19 seperti sekarang ini membuat segala sendi kehidupan menjadi lumpuh. Dunia usaha saat ini mengalami kelumpuhan total sehingga mengakibatkan kegiatan ekonomi bisnis menjadi terganggu, Pebisnis banyak yang mengalami penurunan omset usaha. Menurut Erlangga (2020) mengatakan bahwa omset UMKM secara keseluruhan selama pandemi turuh hingga $30 \%$. Berbagai instansi di beberapa daerah mengalami dampak dari adanya penurunan omset akibat pandemi, salah satunya adalah UMKM. Industri UMKM saat ini mengalami penurunan akibat pandemi dikarenakan adanya instruksi social distancing yang melakukan pembatasan terhadap berbagai aktivitas di masyarakat sebagai upaya untuk menekan penyebaran virus corona. 
Berbagai usaha dilakukan oleh pemerintah agar UMKM mampu dibangkitkan kembali untuk memutar roda perekonomian di tengah pandemi. Salah satunya menurut Pakpahan (2020) adalah dengan melakukan transaksi secara daring yang meminimalisir kontak langsung antara penjual dan pembeli. Hal ini dilakukan sehubungan dengan kebijakan new normal yang dilakukan pemerintah agar tetap menghidupkan perekonomian. Atas dasar itulah, UMKM melakukan perubahan strategi bisnis agar konsumen dapat bertransaksi tanpa harus bertatap muka dengan penjual (Voss, 2014).

Salah satu usaha yang dilakukan adalah dengan perubahan strategi bisnis berbasis smartphone atau android untuk menjaga agar tidak terjadi interaksi berlebihan yang dapat memacu penyebaran virus corona. UMKM dalam hal ini harus melakukan penyesuian dengan sistem tersebut sehingga bisnis yang dijalankan nantinya akan bersifat daring dan tidak memerlukan tatap muka. Pemanfaatan teknologi menjadi suatu hal yang perlu dilakukan untuk memperkuat perekonomian (Murwatiningsih, et al, 2016). Hal ini dilakukan untuk tetap menjalankan roda perekonomian melalui UMKM di tengah situasi pandemi, karena pada hakikatnya ekonomi harus tetap berjalan untuk memenuhi kebutuhan sehari-hari (Lukas, et al, 2010).

Salah satu UMKM yang menjadi tujuan bagi peneliti untuk melakukan observasi adalah UMKM di Kelurahan Joglo, Kecamatan Banjarsari. UMKM tersebut merupakan pusat dari segala UMKM kecil di sekitar Kecamatan Banjarsari. Adapun peneliti tertarik untuk melakukan penelitian tentang pemanfaatan smartphone dan media sosial pada UMKM tersebut dikarenakan peneliti memiliki keinginan untuk mengetahui pemanfaatan media sosial dan smartphone pada situasi pandemi dalam rangka peningkatan perekonomian melalui UMKM.

\section{METODE PELAKSANAAN}

1) Khalayak Sasaran Strategis

Sasaran dari pengabdian ini adalah pegiat UMKM di Kelurahan Joglo, Kecamatan Banjarsari. UKM ini memiliki tujuan mengentaskan memberikan ladang pekerjaan bagi warga di sekitar Kelurahan Joglo, Kecamatan Banjarsari. Lembaga ini juga bertujaun untuk mengoptimalkan sumber daya di sekitar daerah tersebut sebagaimana tujuan dari adanya UMKM (Adriana, 2010). Hal ini juga bertepatan dengan Pasar Legi di daerah tersebut sehingga sumber daya yang ada dapat tertampung. Pelaksanaan kegiatan pengabdian ini pada tanggal 13 Februari 2021 dengan 20 peserta UMKM di lingkungan Kelurahan Joglo

\section{2) Metode}

Metode pelaksanaan penelitian berbasis pengabdian dilaksanakan dalam tiga tahapan.

Perinciannya adalah sebaga berikut.

1. Ceramah

Menurut Ghorbani (2013) ceramah dilakukan dengan memberikan pemahaman tentang promosi online dan aplikasi pembukuan. Hasil yang akan dicapai nantinya adalah Memahami tentang promosi online dan aplikasi pembukuan

2. Pendampingan

Menurut Guspul (2016) pendampingan dilakukan agar tujuan yang dicanangkan dalam penelitian dapat terlaksana dengan baik. Pendampingan dilakukan berupa penggunaan sosial media untuk promosi online dan aplikasi pembukuan. Diharapkan pegiat UMKM dapat menggunakan sosial media untuk promosi online dan aplikasi pembukuan

3. Pemecahan masalah.

Pemecahan masalah diperlukan untuk mendapatkan hasil penelitian yang relevan dengan permasalahan yang terjadi (Hotima, et al, 2017). Penggunaan sosial media unntuk promosi online dan aplikasi pembukuan dengan tujuan agar dapat menggunakan sosial media untuk promosi online dan aplikasi pembukuan. 


\section{3) Evaluasi}

Penilaian yang dilakukan adalah sebagai berikut.

1. Memantau dan membantu peserta pelatihan dalam memahami penggunaan platform digital dalam pemasaran produk. Selain itu, tim pelaksana melakukan pendampingan terhadap proses pembukuan dengan berbagai aplikasi yang ditawarkan terkait dengan pembukuan laporan keuangan.

2. Evaluasi yang dilakukan meliputi hasil publikasi pemasaran produk, rekapitulasi laporan keuangan, dan produk yang berhasil dijual dari pemasaran produk tersebut.

\section{HASIL DAN PEMBAHASAN}

Hasil dari penelitian yang dilakukan menunjuk pada keberhasilan untuk mengembangkan UMKM melalui pemasaran pada platform digital berupa smartphone dan berbagai media sosial (Rahmana, 2009). Hasil dari pengabdian juga dapat memberikan edukasi tentang penggunaan teknologi pada pembukuan pengelolaan keuangan di UMKM Joglo. Secara nyata, para warga yang aktif di UMKM Joglo sudah dapat membuat penawaran iklan sederhana melalui smartphone mereka masing-masing. Selain itu, para warga pegiat UMKM juga dapat membuat laporan keuangan sederhana sesuai dengan materi yang diajarkan. Setelah dilakukan pelatihan, partisipan juga sangat responsive dalam bertanya dan bisa dalam melakukan praktek penggunaan smartphone untuk promosi online dan aplikasi pembukuan untuk usaha mereka.

Pengabdian dilakukan dengan menumbuhkan semangat untuk selalu melakukan upgrade terhadap berbagai perkembangan teknologi yang terjadi saat ini (Raselawati, 2011). Penyuluhan juga dilakukan dengan tujuan untuk memberikan edukasi tentang pemasaran produk dan pembukuan laporan keuangan melalui smartphone yang menjadi kebutuhan komunikasi dan informasi dalam kehidupan sehari-hari. Pemberian edukasi dalam bentuk ATM (Amati tiruan dan modifikasi) berbagai hal baru juga menjadi fokus utama bagi tim pelaksana dalam memberkan penyuluhan.

Terkait dengan hal tersebut, respon dari peserta UMKM Joglo positif. Selama penyuluhan berlangsung banyak pegiat UMKM di Joglo menunjukkan ketertarikan terhadap materi yang diberikan dan mencoba mengakses aplikasi yang ditawarkan oleh tim pelaksana. Penyuluhan yang dilakukan menjadi wujud pelatihan keterampilan yang dilakukan dalam rangka pengoptimalan teknologi pemasaran produk dan pembukuan laporan keuangan pada UMKM Joglo.

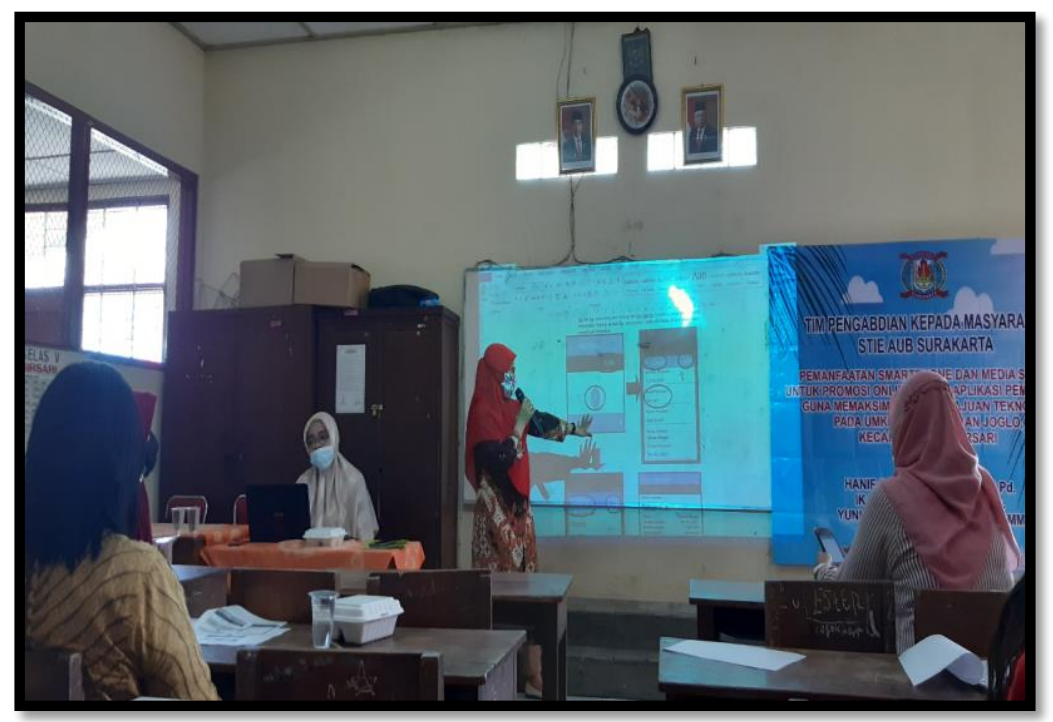

Gambar 1. Pelatihan dan Pendampingan Pemanfaatan Smartphone untuk Promosi Online dan Pembukuan 


\section{KESIMPULAN}

Kesimpulan

Pemanfaatan smartphone dan aplikasi melalui media sosial mendorong kreativtas pegiat UMKM Joglo dalam hal pemsaran produk dan pembukuan laporan keuangan sehingga dapat mendorong kegiatan perekonomian bagi warga Kelurahan Joglo, Kecamatan Banjarsari. Akan tetapi, pelatihan ini memiliki beberapa faktor penghalang sebagai berikut.

1. Kesibukan dari masing-pegiat UMKM sehingga tidak sedikit yang tidak menghadiri pelatihan

2. Jenjang pendidikan peserta yang rendah dan memiliki kesenjangan dengan peserta lan mengakibatkan perbedaan pemahaman ketika pelatihan berlangsung

3. Kurangnya minat dari peserta yang menyadarti pentingnya optimalisasi platform digital

\section{UCAPAN TERIMA KASIH}

Penulis mengucapkan terima kasih kepada STIE Adi Unggul Bhirawa yang telah memberi dukungan dana dalam pelaksanaan pengabdian ini.

\section{DAFTAR REFERENSI}

Adriana Dkk. (2010). Kompetensi SDM UKM dan Pengaruhnya Terhadap Kinerja UKM di Surabaya. Jurnal Manajemen Dan Kewirausahaan, 12 (1), 42-55

Ciputra. Bisnis dan tujuan kewirausahaan. http://ciputrauceo.net/blog/2016/3/7/bisnis-dan-tujuan-

kewirausahaan. Diakses pada 20 Maret 2021

Ghorbani, Somayeh. (2013). Investigating the Effect of Positive Discipline on theLearning Process and its Achieving Strategies with Focusing on the Students' Abilities International. Journal of Academic Research in Business and Social Sciences, 3 (5), 1-11

Gunadi, Ardian. Bangkitnya UMKM. http://ekonomi.kompas.com/read/2017/04/04/ 123000526/potensibangkitnya-umkm-dan-industri-kreatif-melalui-peer-to-peer-lending-. Diakses pada 20 Maret 2021

Guspul, Ahmad. (2016). Pengaruh Orientasi Pasar,Inovasi dan Orientansi KewirausahaanTerhadap Kinerja Pemasaran UMKM Batako di Kepil Wonosobo. Jurnal PPKM III, 2 (3), 1-17

Hotima, Siti Husnul dan Yusianti, Heka Rahma. 2017. Pengaruh Inovasi Produk dan Orientasi Pasar Terhadap Keunggulan Bersaing pada UKM Pia UD. Barokah Putra Jaya Sumbera Ambulu. Dian IImu, $16(2), 19-34$

Lukas, Bryan A., and O.C. Ferrel., 2010. The Effect of Market Orientation on Product Inovation. Journal of The Academy Marketing Science, 2 (28), 239-247

Murwatiningsih, Witiastuti, R. S \& Oktarina, N. (2016). Improving Business Performance through Creative Entrepreneur, Superior Business and Entrepreneurial Networks. International Journal of the Computer, the Internet and Management, 24 (3), 23-26

Pakpahan, Aknolt Kristian. (2020). COVID-19 dan Implikasi Bagi Usaha Mikro, Kecil, dan Menengah. Jurnal FISIP Unpar, 1-6

Rahmana, Arif. (2009). Peranan Teknologi Informasi dalam Peningkatan Daya Saing Usaha Kecil Menengah.Seminar Nasional Aplikasi Teknologi Informasi (SNATI). Yogyakarta, 20 Juni 2009.

Raselawati, Ade. (2011). Pengaruh Perkembangan Usaha Kecil Menengah terhadap Pertumbuhan Ekonomi Pada Sektor UKM di Indonesia. UIN. Syarif Hidayatullah. Jakarta.

Voss, G. B. (2014). Strategic Orientation and Firm Performance in an Artistic Environment. Journal of Marketing, 64 (1), 67-83. 